\title{
Biofortification of maize with zinc and iron not only enhances crop growth but also improves grain quality
}

\author{
Zunaira Anwar'1, Zyma Basharat ${ }^{1}$, Muhammad Bilal Hafeez ${ }^{2}$, Shahbaz Khan ${ }^{*}$, Noreen Zahra ${ }^{1}$, Zayrah \\ Rafique$^{1}$, Muhammad Maqsood ${ }^{2}$ \\ ${ }^{1}$ Department of Botany, University of Agriculture, Faisalabad (38040), Pakistan \\ ${ }^{2}$ Department of Agronomy, University of Agriculture, Faisalabad (38040), Pakistan
}

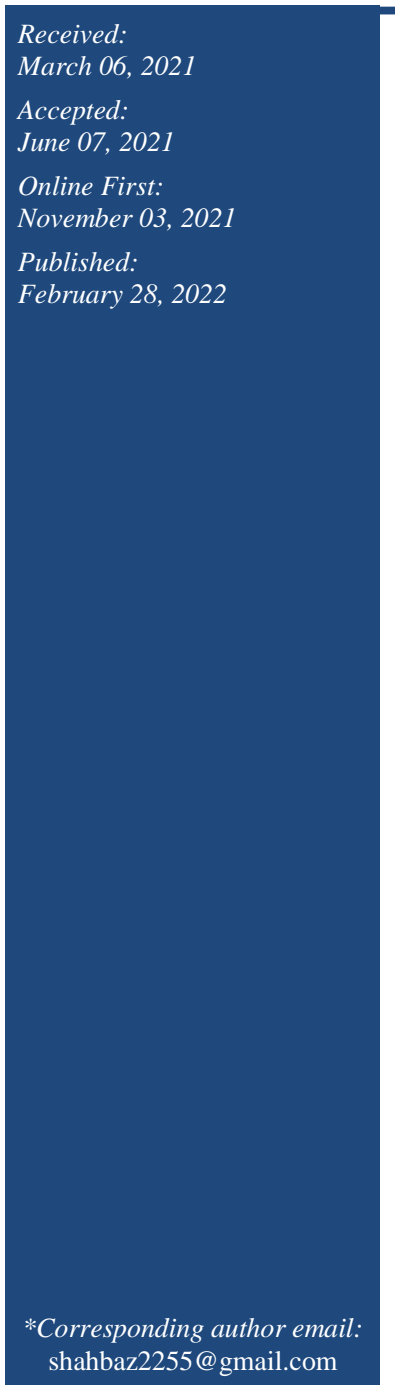

\begin{abstract}
Hidden hunger is an emerging challenge for scientists, especially connected to the agriculture sector because over two billion people are facing it globally. This issue is more common in developing countries which have less access to a diverse diet due to their low income. Different potential practices are introduced to minimize the pressure of malnutrition but agronomic biofortification is being considered best practice to improve the contents of micronutrient in grains. A field based study was executed to explore the impact of zinc sulphate $\left(\mathrm{ZnSO}_{4}\right)$ and iron sulphate $\left(\mathrm{FeSO}_{4}\right)$ on productivity and grain quality of maize crop. Sole and combined application of $\mathrm{ZnSO}_{4}$ and $\mathrm{FeSO}_{4}$ either via soil or/and plant foliage not only enhanced the yield attributes of maize crop but grain quality was also improved. Soil supplementation of $\mathrm{ZnSO}_{4}\left(10 \mathrm{~kg} \mathrm{ha}^{-1}\right)$ produced maximum plant height and cob weight. Combined treatment of $\mathrm{ZnSO}_{4}\left(10 \mathrm{~kg} \mathrm{ha}^{-1}\right)$ and $\mathrm{FeSO}_{4}\left(12 \mathrm{~kg} \mathrm{ha}^{-1}\right)$ through soil produced more grains per cob, 1000-grain weight, biological and grain yields. Foliar applied $0.1 \%$ $\mathrm{ZnSO}_{4}$ and $0.3 \% \mathrm{FeSO}_{4}$ produced highest chlorophyll contents. Foliar treatment of $0.1 \% \mathrm{ZnSO}_{4}$ and $0.3 \% \mathrm{FeSO}_{4}$ improved the concentration of zinc and iron in grains, respectively. Combined treatment of $10 \mathrm{~kg} \mathrm{ha}^{-1}$ of $\mathrm{ZnSO}_{4}$ and $12 \mathrm{~kg} \mathrm{ha}^{-1}$ of $\mathrm{FeSO}_{4}$ through soil improves the yield attributes while foliar spray of $0.1 \% \mathrm{ZnSO}_{4}$ and $0.3 \%$ $\mathrm{FeSO}_{4}$ enhances quality parameters. Overall, foliar spray approach is more applicable regarding nutrients availability for optimum development and growth of crop and improved grain quality.
\end{abstract}

Keywords: Chlorophyll, Foliar application, Hidden hunger, Maize yield, Micronutrients.

\section{How to cite this:}

Anwar Z, Basharat Z, Hafeez MB, Khan S, Zahra N, Rafique Z and Maqsood M, 2022. Biofortification of maize with zinc and iron not only enhances crop growth but also improves grain quality. Asian J. Agric. Biol. 2022(2): 202102079. DOI: https://doi.org/10.35495/ajab.2021.02.079

This is an Open Access article distributed under the terms of the Creative Commons Attribution 3.0 License. (https://creativecommons.org/licenses/by/3.0), which permits unrestricted use, distribution, and reproduction in any medium, provided the original work is properly cited. 


\section{Introduction}

Micronutrient malnutrition is affecting rural populations residing in developing countries with less access to a diverse diet due to their less purchasing power (Tsakirpaloglou et al., 2019; Kumar et al., 2019). Globally, over two billion people are facing hidden hunger (micronutrients deficiency), and it is an emerging challenge for scientists, especially connected to agriculture sector (WHO, 2016). In human, malnutrition is mainly caused by vitamin A, $\mathrm{Zn}, \mathrm{Fe}$, selenium (Se) and iodine (I) deficiency (Haider and Bhutta, 2009; Hess and King, 2009). Particularly $\mathrm{Fe}$ and $\mathrm{Zn}$ metal deficiencies, are affecting over $50 \%$ of world community because they depend on cereal crops, chiefly rice, maize and wheat for their regular diet (Ramzan et al., 2020).

Both $\mathrm{Zn}$ and $\mathrm{Fe}$ are indispensable nutrients for biological systems in plants, humans, and animals (Broadley et al., 2007; Failla, 2003). In human, Fe is needed for haemoglobin formation (oxygen transport), psychomotor development, and resistance to infection (Stoltzfus, 2001). Its clinical deficiency is also associated with pallor (anaemia), dizziness, reduced work capacity and reduced intellectual performance and pregnancy-related issues, i.e., low birth weight and mortality (Lynch, 2003; CDC, 2010). In humans, $\mathrm{Zn}$ is needed for activation of over 300 enzymes, maintenance of sensory functions, physical growth and development, immune system, and neurobehavioral development (Gibson, 2012; Levenson and Morris, 2011). Many health impediments, like poor physical growth, damage to DNA, central nervous, gastrointestinal, epidermal, reproductive, skeletal and immune systems may occur due to $\mathrm{Zn}$ deficiency (Hambidge and Walravens, 1982; Prasad, 2006). In Pakistan, more than $40 \%$ mothers and one-third children are under $\mathrm{Zn}$ malnutrition, with a higher rate in rural communities (MINH, 2009).

Worldwide, maize is growing under wide range of soil and climatic conditions for grain and fodder production (Ranum et al., 2014). Maize ranks third vital cereal crop after wheat and rice that contributes almost $0.5 \%$ grand domestic production (GOP, 2019) Maize is also considered as a staple food for greater than 200 million people, and it can be expected that globe population will be eight billion in 2025 (USDA, 2008; Lutz et al., 2001). It is known as a queen of cereals because of high monetary value as it is also treated on commercial scale to make a variety of products for the consumption of human, livestock and poultry industries (Harris et al., 2007). Due to highest yield potential among cereals, it can be paramount crop to overcome global nutrition (Tariq and Iqbal, 2010).

Among different possible agricultural approaches to conquer the malnutrition, the agronomic biofortification is top ranked approach to improve the grain Fe and Zn contents (Borrill et al., 2014; Hassan et al., 2019; Cakmak et al., 2010). It is achieved through the application of micronutrient to crop foliage directly and/or soil (De Valença et al., 2017; Zahra et al., 2020). It can be implemented easily being more sustainable and economical as compared to other techniques including genetic engineering (Cakmak, 2008). Ngozi (2013) reported that agronomic biofortification of the crops is an emerging practice to overwhelm malnutrition particularly metal deficiencies in the developing world. Considering the above mentioned rationale, the current study was designed to study the following objective; i) to assess the either sole and/or combined influence of $\mathrm{Zn}$ and $\mathrm{Fe}$ on quality, growth and yield of maize crop, ii) to compare the efficiency of two application approaches, i.e. foliar and soil application.

\section{Material and Methods}

\section{Experimental particulars}

The present field-based trial was conducted to explore the impact of $\mathrm{Zn}$ and $\mathrm{Fe}$ on grain quality and yield of maize crop. Seeds of maize hybrid (Soni dharti-626) were collected from Sohni Dharti International Seed Company, Sahiwal-Pakistan. Seeds were sown at research area of Agronomy Farm, Universsity of Agriculture, Faislabad-Pakistan during crop growing season of 2018. Site soil was ploughed to a depth of $30 \mathrm{~cm}$ and ridges of $30 \mathrm{~cm}$ in height and $75 \mathrm{~cm}$ of spacing were prepared. Two seeds were planted on the top of all ridges with space of $25 \mathrm{~cm}$ between hills. Every experimental unit consist of 4 ridges that were $3 \mathrm{~m}$ in length. The experimental soil of area, under study, was sandy loam having following properties; $\mathrm{pH}$ 8.1, EC 1.45 $\mathrm{dS} \mathrm{m}^{-1}$, organic matter $0.81 \%$, total nitrogen $(\mathrm{N})$ $0.08 \%$, phosphorus contents $(\mathrm{P}) 8.2 \mathrm{ppm}$, potassium contents (K) 200 ppm, DTPA- Extractable iron (Fe) $2.54 \mathrm{mg} \mathrm{kg}^{-1}$, zinc (Zn) $0.45 \mathrm{mg} \mathrm{kg}^{-1}$. 


\section{Crop husbandry}

After almost 2 weeks of sowing, thinning was done to maintain the plant population and a basal dose of NPK fertilizer (230:145:92) was applied by using urea, DAP and sulphate of potash fertilizer. $\mathrm{ZnSO}_{4}$ and $\mathrm{FeSO}_{4}$ were used as sources of micronutrient. At sowing, one-third of nitrogen and all of the phosphorus, potash, $\mathrm{ZnSO}_{4}$ and $\mathrm{FeSO}_{4}$ doses were applied as a basel dose. The remaining dose of nitrogen was supplemented in equal splits with $1^{\text {st }}$ and $2^{\text {nd }}$ irrigation while foliar application of $\mathrm{ZnSO}_{4}$ and $\mathrm{FeSO}_{4}$ at silking and grain filling stage. Experimental units were weeded twice in the course of the growing duration.

To study the above mentioned objectives, following treatments were applied:

- Control (foliar spray of water)

- Foliar spray of $0.1 \% \mathrm{ZnSO}_{4}$

- Foliar spray of $0.3 \% \mathrm{FeSO}_{4}$

- Foliar spray of $0.1 \% \mathrm{FeSO}_{4}$ and $0.3 \% \mathrm{FeSO}_{4}$

- Soil supplementation of $10 \mathrm{~kg} \mathrm{ha}^{-1}$ of $\mathrm{ZnSO}_{4}$

- Soil supplementation of $12 \mathrm{~kg} \mathrm{ha}^{-1}$ of $\mathrm{FeSO}_{4}$

- Soil supplementation of $10 \mathrm{~kg} \mathrm{ha}^{-1}$ of $\mathrm{ZnSO}_{4}$ and $12 \mathrm{~kg} \mathrm{ha}^{-1}$ of $\mathrm{FeSO}_{4}$

- Foliar spray of $0.1 \% \mathrm{ZnSO}_{4} \& 0.3 \% \mathrm{FeSO}_{4}$ and Soil supplementation of $10 \mathrm{~kg} \mathrm{ha}^{-1}$ of $\mathrm{ZnSO}_{4}$ and $12 \mathrm{~kg} \mathrm{ha}^{-1}$ of $\mathrm{FeSO}_{4}$

Biochemical analysis and quality attributes

Arnon (1949) method was used for the determination of the chlorophyll pigments ( $a$ and $b$ ). Atomic Absorption Spectrophotometer was used to measure the amount of $\mathrm{Zn}$ and $\mathrm{Fe}$ in maize grains according to method described by AOAC (1990). The total soluble protein was measured according to Bradford method (1976).

\section{Agronomic parameters}

Data of yield and its attributes were recorded at crop maturity. Plant population was counted at harvesting $\left(\mathrm{m}^{-2}\right)$. Ten plants were selected randomly from each experimental unit to record the data of plant height. Plant height of individual plant was measured with a meter rod from base to top and then averaged. Number of grain rows per cob, cob weight and its length, and grains per cob were determined manually from the selected cobs. For biological and grain yield, plants harvested from a row of one meter length and converted in to per hectare and weighed with weighing balance. Harvest index (\%) was estimated by dividing the grain yield with biological yield.

\section{Statistical analysis}

A randomized complete block design (RCBD) having three replications was adopted. Statistical package (Statistix 8.1) was used to analyse and evaluate the collected data. ANOVA (analysis of variance) technique proposed by Fisher was followed to observe the statistical differences among the variance and means of treatments.

\section{Results}

Foliar spray of $0.1 \% \mathrm{ZnSO}_{4} \& 0.3 \% \mathrm{FeSO}_{4}$ produced maximum chlorophyll a content in maize (Fig. 1a) that was at par statistically with foliar application of $\mathrm{Fe} @ 3 \%$ and soil applied Zn@10 kg ha ${ }^{-1}$, whereas minimum in control. Similarly, foliar spray of $0.1 \%$ $\mathrm{ZnSO}_{4} \& 0.3 \% \mathrm{FeSO}_{4}$ produced highest chlorophyll $\mathrm{b}$ and total chlorophyll contents (Fig. 1b \& c).

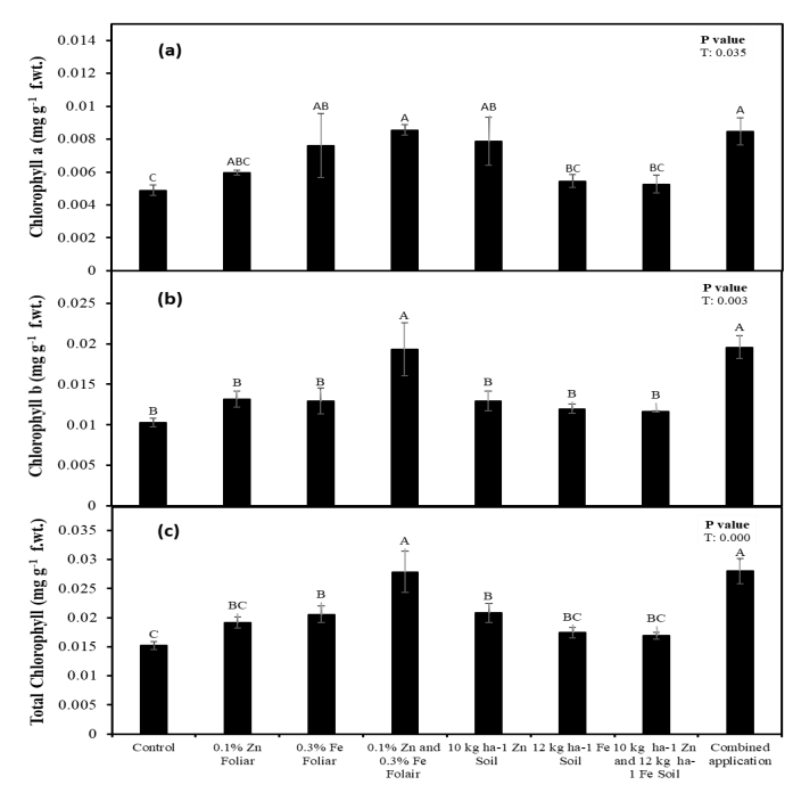

Figure-1:Influence of foliar and soil supplied $\mathrm{ZnSO}_{4}$ and $\mathrm{FeSO}_{4}$ on chlorophyll $a$ (a), $b$ (b) and total chlorophyll in maize (c).

Foliar application of Fe @ 3\% produced maximum Fe contents in maize grain while minimum in control (Fig. 2a). Foliar spray of Zn @ $0.1 \%$ bring in highest $\mathrm{Zn}$ contents in maize grain while lowest in control 
(Fig. 2b). All the treatments either sole or combined through foliar spray or soil application reduced the protein contents in maize grain (Fig. 2c). Highest

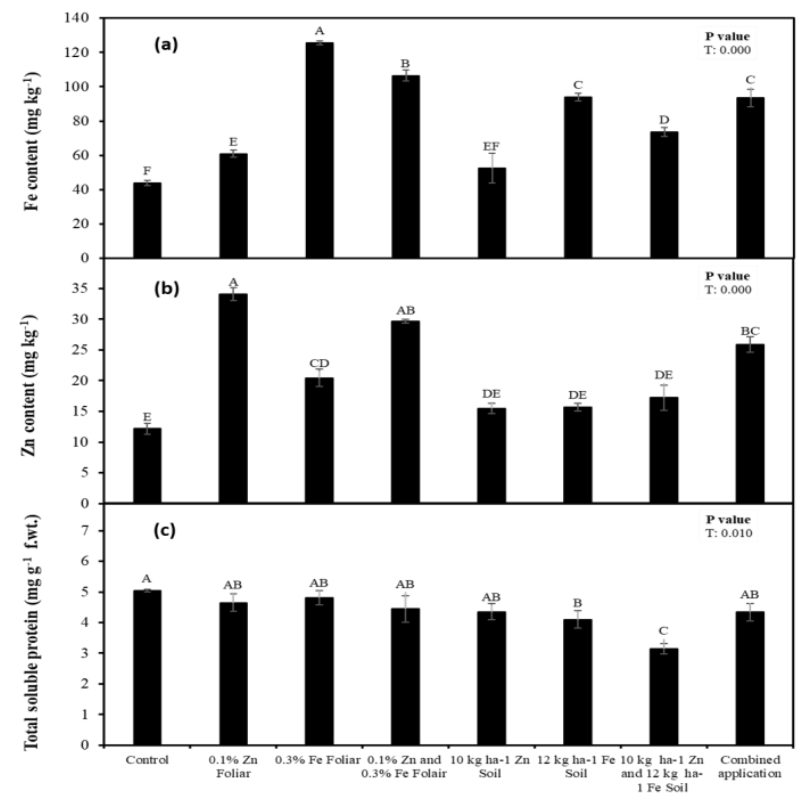

Figure-2: Influence of foliar and soil supplied $\mathrm{ZnSO}_{4}$ and $\mathrm{FeSO}_{4}$ on $\mathrm{Fe}$ contents (a) $\mathrm{Zn}$ contents (b) and total soluble proteins in maize grains (c). protein contents were observed in those grains which received no exogenous treatment.

The number of leaves plant ${ }^{-1}$ were not significantly increased by external treatments of $\mathrm{Zn}$ and $\mathrm{Fe}$ (Table 1). Soil applied Zn @ $10 \mathrm{~kg} \mathrm{ha}^{-1}$ produced maximum plant height as compared to other treatments (Table 1). Cob length was not affected by exogenous application of $\mathrm{Zn}$ and $\mathrm{Fe}$ (Table 1) while cob weight was significantly affected. Soil supplemented Zn@ $10 \mathrm{~kg} \mathrm{ha}^{-1}$ produced highest cob weight (Table 1) that was statistically at par with soil supplementation of $\mathrm{Zn}$ and Fe @ 10 and $12 \mathrm{~kg}$ of $\mathrm{ZnSO}_{4}$ and $\mathrm{FeSO}_{4}$ per hectare. Number of grain rows were not affected by treatment application (Table 1). Data regarding number of grains $\mathrm{cob}^{-1}, 1000$-grain weight, biological and grain yield and harvest index are presented in table 2. Application of $10 \mathrm{~kg}$ of $\mathrm{ZnSO}_{4}$ and $12 \mathrm{~kg}$ of $\mathrm{FeSO}_{4}$ through soil produced maximum grains $\mathrm{cob}^{-1}$, 1000-grain weight, biological as well as grain yield, however, harvest index was statistically nonsignificant (Table 2).

Table-1: Influence of foliar and soil supplied $\mathrm{ZnSO}_{4}$ and $\mathrm{FeSO}_{4}$ on number of leaves per plant, plant height, cob length, cob weight and grain rows per cob in maize.

\begin{tabular}{|c|c|c|c|c|c|}
\hline Treatments & $\begin{array}{c}\text { Number of leaves } \\
\text { per plant }\end{array}$ & $\begin{array}{l}\text { Plant height } \\
(\mathbf{c m})\end{array}$ & $\begin{array}{l}\text { Cob length } \\
(\mathbf{c m})\end{array}$ & $\begin{array}{l}\text { Cob weight } \\
(\mathrm{g})\end{array}$ & $\begin{array}{l}\text { Grain rows } \\
\text { per cob }\end{array}$ \\
\hline Control (foliar application of $\mathrm{H}_{2} \mathrm{O}$ ) & $14 \pm 0.352$ & $181.1 \pm 3.78 \mathrm{c}$ & $18.15 \pm 0.029$ & $230.4 \pm 3.600 \mathrm{~d}$ & $15 \pm 0.352$ \\
\hline Foliar application of $0.1 \% \mathrm{ZnSO}_{4}$ & $15 \pm 0.066$ & $192.4 \pm 3.03 \mathrm{ab}$ & $18.78 \pm 0.450$ & $238.0 \pm 4.244 \mathrm{~cd}$ & $15 \pm 0.230$ \\
\hline Foliar application of $0.3 \% \mathrm{FeSO}_{4}$ & $15 \pm 0.416$ & $190.5 \pm 1.99 \mathrm{~b}$ & $18.24 \pm 0.140$ & $241.8 \pm 3.120 \mathrm{~cd}$ & $15 \pm 0.417$ \\
\hline $\begin{array}{l}\text { Foliar application of } 0.1 \% \mathrm{ZnSO}_{4} \text { and } 0.3 \% \\
\mathrm{FeSO}_{4}\end{array}$ & $14 \pm 0.133$ & $191.6 \pm 2.45 \mathrm{ab}$ & $18.36 \pm 0.284$ & $242.0 \pm 2.017 \mathrm{~cd}$ & $15 \pm 0.230$ \\
\hline Soil application of $10 \mathrm{~kg}$ ha- 1 of $\mathrm{ZnSO}_{4}$ & $14 \pm 0.266$ & $200.0 \pm 2.51 \mathrm{a}$ & $18.52 \pm 0.184$ & $264.3 \pm 1.876 \mathrm{a}$ & $15 \pm 0.666$ \\
\hline Soil application of $12 \mathrm{~kg}$ ha- 1 of $\mathrm{FeSO}_{4}$ & $14 \pm 0.176$ & $197.6 \pm 3.16 \mathrm{ab}$ & $18.27 \pm 0.439$ & $246.3 \pm 5.223 \mathrm{bc}$ & $16 \pm 0.400$ \\
\hline $\begin{array}{l}\text { Soil application of } 10 \mathrm{~kg} \text { ha- } 1 \text { of } \mathrm{ZnSO}_{4} \text { and } 12 \\
\text { kg ha- } 1 \text { of } \mathrm{FeSO}_{4}\end{array}$ & $15 \pm 0.266$ & $199.5 \pm 2.52 \mathrm{ab}$ & $18.54 \pm 0.270$ & $260.3 \pm 3.186 \mathrm{a}$ & $15 \pm 0.581$ \\
\hline $\begin{array}{l}\text { Foliar application of } 0.1 \% \mathrm{ZnSO}_{4} \& 0.3 \% \mathrm{FeSO}_{4} \\
\text { and Soil application of } 10 \mathrm{~kg} \mathrm{ha}^{-1} \text { of } \mathrm{ZnSO}_{4} \text { and } \\
12 \mathrm{~kg} \mathrm{ha}^{-1} \text { of } \mathrm{FeSO}_{4}\end{array}$ & $14 \pm 0.176$ & $197.0 \pm 4.041 \mathrm{ab}$ & $18.40 \pm 0.248$ & $253.9 \pm 1.931 \mathrm{ab}$ & $15 \pm 0.266$ \\
\hline $\operatorname{LSD}(\mathrm{P}=0.05)$ & 0.808 & 9.3123 & 0.7306 & 10.411 & 1.316 \\
\hline
\end{tabular}


Table-2: Influence of foliar and soil supplied $\mathrm{ZnSO}_{4}$ and $\mathrm{FeSO}_{4}$ on grains per cob, 1000-grain weight, biological yield, grain yield and harvest index in maize.

\begin{tabular}{|c|c|c|c|c|c|}
\hline Treatments & $\begin{array}{c}\text { Grains per } \\
\text { cob }\end{array}$ & $\begin{array}{c}\text { 1000-grain weight } \\
(\mathrm{g})\end{array}$ & $\begin{array}{c}\begin{array}{c}\text { Biological yield (t } \\
\left.\mathrm{ha}^{-1}\right)\end{array} \\
\end{array}$ & $\begin{array}{c}\text { Grain yield } \\
\left(\mathrm{kg} \mathrm{ha}^{-1}\right)\end{array}$ & $\begin{array}{c}\text { Harvest index } \\
(\%)\end{array}$ \\
\hline Control (foliar application of $\mathrm{H}_{2} \mathrm{O}$ ) & $511 \pm 5.73 \mathrm{~d}$ & $303.0 \pm 4.041 \mathrm{~d}$ & $22.69 \pm 462.9 \mathrm{c}$ & $3990 \pm 89.5 \mathrm{e}$ & $17.62 \pm 0.732$ \\
\hline Foliar application of $0.1 \% \mathrm{ZnSO}_{4}$ & $528 \pm 10.73 \mathrm{~cd}$ & $330.0 \pm 3.000 \mathrm{~cd}$ & $25.32 \pm 201.8 \mathrm{~b}$ & $4742 \pm 244.1 \mathrm{~d}$ & $18.74 \pm 1.107$ \\
\hline Foliar application of $0.3 \% \mathrm{FeSO}_{4}$ & $532 \pm 11.30 \mathrm{~cd}$ & $345.0 \pm 5.686 \mathrm{bcd}$ & $25.00 \pm 801.8 \mathrm{bc}$ & $4458 \pm 38.8 \mathrm{de}$ & $17.88 \pm 0.728$ \\
\hline $\begin{array}{l}\text { Foliar application of } 0.1 \% \mathrm{ZnSO}_{4} \text { and } \\
0.3 \% \mathrm{FeSO}_{4}\end{array}$ & $543 \pm 7.62 \mathrm{bc}$ & $330.0 \pm 4.582 \mathrm{~cd}$ & $26.39 \pm 801.8 \mathrm{~b}$ & $4903 \pm 338.8 \mathrm{~cd}$ & $18.61 \pm 1.405$ \\
\hline Soil application of $10 \mathrm{~kg} \mathrm{ha}^{-1}$ of $\mathrm{ZnSO}_{4}$ & $554 \pm 8.96 \mathrm{abc}$ & $372.0 \pm 4.041 \mathrm{abc}$ & $31.02 \pm 462.9 \mathrm{a}$ & $5772 \pm 767.5 \mathrm{ab}$ & $18.66 \pm 0.781$ \\
\hline Soil application of $12 \mathrm{~kg} \mathrm{ha}^{-1}$ of $\mathrm{FeSO}_{4}$ & $548 \pm 9.73 \mathrm{abc}$ & $375.0 \pm 7.937 \mathrm{abc}$ & $31.00 \pm 1224.8 \mathrm{a}$ & $5378 \pm 172.4 \mathrm{bc}$ & $17.34 \pm 0.207$ \\
\hline $\begin{array}{l}\text { Soil application of } 10 \mathrm{~kg} \mathrm{ha}^{-1} \text { of } \mathrm{ZnSO}_{4} \\
\text { and } 12 \mathrm{~kg} \mathrm{ha}^{-1} \text { of } \mathrm{FeSO}_{4}\end{array}$ & $570 \pm 6.62$ a & $405.0 \pm 6.429 \mathrm{a}$ & $32.41 \pm 936.5 \mathrm{a}$ & $6156 \pm 111.0 \mathrm{a}$ & $19.00 \pm 0.498$ \\
\hline $\begin{array}{l}\text { Foliar application of } 0.1 \% \mathrm{ZnSO}_{4} \& \\
0.3 \% \mathrm{FeSO}_{4} \text { and Soil application of } 10 \\
\mathrm{~kg} \mathrm{ha}^{-1} \text { of } \mathrm{ZnSO}_{4} \text { and } 12 \mathrm{~kg} \mathrm{ha}^{-1} \text { of } \\
\mathrm{FeSO}_{4}\end{array}$ & $566 \pm 9.25 \mathrm{ab}$ & $384.0 \pm 6.000 \mathrm{ab}$ & $31.48 \pm 925.9 \mathrm{a}$ & $5473 \pm 283.1 \mathrm{bc}$ & $17.40 \pm 0.923$ \\
\hline $\operatorname{LSD}(\mathrm{P}=0.05)$ & 27.75 & 16.240 & 2331.3 & 578.9 & 2.608 \\
\hline
\end{tabular}

\section{Discussion}

Our outcomes supported the hypothesis that the different amount of zinc and iron treatments either through soil or/and foliar significantly improves the chlorophyll contents, quality of grains, and grain yield in maize crop than control. The improvement in grain yield is associated to the cob weight, grains cob ${ }^{1}$ and weight of 1000 -grains. In this study, maximum grain yield was recorded when combined application of zinc and iron was supplemented (Table 2). The improvement in attributes of yield of maize crop might be due to involvement of zinc and iron in biochemical processes, including photosynthesis. Outcomes of present experimentation are similar to Saleem et al. (2016), who stated the soil supplementation of $\mathrm{Zn}$ and Fe (each @ $30 \mathrm{~kg} \mathrm{ha}^{-1}$ ) considerably enhanced yield and quality of grains. Similar outcomes were also described by Kanwal et al. (2010) that more $\mathrm{Zn}$ uptake and higher grain yield in corn were noted when $\mathrm{Zn}$ soil supplementation was done@18 kg Zn ha ${ }^{-1}$. These findings are also in line with Mugenzi et al. (2018), who stated the collective effect of $\mathrm{Zn}$ and $\mathrm{Fe}$ enhanced the maize yield, photosynthetic capacity, and grain quality. Eteng et al. (2014) showed a considerable increase in yield of maize with the micronutrients supplementation. Globally, $\sim 50 \%$ of the soils under cultivation of cereal have low levels of available $\mathrm{Zn}$ for plants (Graham and Welch, 1996).

Combined treatment of $\mathrm{Zn}$ and $\mathrm{Fe}$ (soil+foliar) increased accumulation $\mathrm{Zn}$ and $\mathrm{Fe}$ contents (Fig. 2a, b). Maximum $\mathrm{Zn}$ content was noted when $\mathrm{ZnSO}_{4}$ applied @ 0.1\%, and highest amount of Fe content was recorded when $\mathrm{FeSO}_{4}$ was applied @ 0.3\% (Fig. $2 \mathrm{a}, \mathrm{b})$. Highest protein contents were analyzed in control while significantly decreased when combined soil $\mathrm{Zn}$ and Fe supplementation was done (Fig. 2c). Our results are also in line with the findings of Cakmak et al. (2010), who stated that $\mathrm{Zn}$ contents were increased three times in grains by foliar and soil applied $\mathrm{Zn}$, additionally noted that time and method of $\mathrm{Zn}$ application is so important to enhance $\mathrm{Zn}$ concentration in grains. By application of $0.5 \%$ $\mathrm{ZnSO}_{4}$ and $1 \% \mathrm{FeSO}_{4}$ zinc and iron contents were also significantly improved (Pahlavan-Rad and Pessarakli, 2009). Saleem et al. (2016) noted that $\mathrm{Zn}$ and $\mathrm{Fe}$ through foliage considerably enhanced the zinc and iron contents in maize grain. These findings are also in line with Zeidan et al. (2010), they concluded that zinc and iron concentrations in wheat grains were significantly improved by foliar treatment of zinc and iron. Ozturk et al. (2006) also stated that foliar spray improved the zinc content in grain at later growth stages. Sharma and Singh (1990) investigated that zinc absorption through soil to plant was improved by application of $\mathrm{ZnSO}_{4}$ in maizestover.

Foliar spray of $\mathrm{Zn}$ improved the availability of $\mathrm{Zn}$ to plants in comparison with soil application (Zhao et al., 2014). The foliar spray of $\mathrm{Zn}$ is more productive in enhancing grain $\mathrm{Zn}$ concentration of maize crop. Cakmak (2008) reported that the foliar application is better way to improve iron content in grain because clay adsorption and low organic matter reduced the flow of nutrients reported the accumulation of 
micronutrients in the grain with the addition of their fertilizers. Zuchi et al. (2015) investigated that an insufficient supply of other nutrients might prevent the uptake of iron and its translation to shoots and other parts, which may result in reduction of other nutrients. Among plants, nutrients interaction can be antagonistic, synergistic, Liebig-synergistic and/or zero-interactive. These interactions explained that activities of other nutrients may be affected by the supply of specific nutrient that ultimately adversely affect crop yield and growth (Rietra et al., 2017). Usually, Fe deficiency is seen in calcareous soils having high $\mathrm{pH}$ in arid areas (Prasad, 2003). Worldwide, it is estimated that $\mathrm{Zn}(50 \%)$ and $\mathrm{Fe}$ $(30 \%)$ deficiencies are widespread occurring in cultivated soils (Cakmak, 2002). In Pakistan, zinc deficiencies are more extensive, about $70 \%$ soils are deficient of zinc (Imtiaz et al., 2010).

Applied micronutrients and their interactions influence physiological and biochemical processes of plants, which substantially affect quality and yield of grains (Wang et al., 2015). Mugenzi et al. (2018) stated that iron and zinc application, either sole or combined had no significant influence on protein content. However, in this study protein content considerably reduced where sole or combined zinc and iron foliar or in soil was applied in comparison with control. Ramzani et al. (2017) noted that protein content increased by $64 \%$ by $\mathrm{Fe}$ application in comparison with control.

\section{Conclusion}

Foliar spray of $0.1 \% \quad \mathrm{ZnSO}_{4}$ and $0.3 \% \quad \mathrm{FeSO}_{4}$ improved the contents of zinc and iron in grains, respectively. Combined treatment of $10 \mathrm{~kg} \mathrm{ha}^{-1}$ of $\mathrm{ZnSO}_{4}$ and $12 \mathrm{~kg} \mathrm{ha}^{-1}$ of $\mathrm{FeSO}_{4}$ through soil improves the yield attributes while foliar application of $0.1 \%$ $\mathrm{ZnSO}_{4}$ and $0.3 \% \mathrm{FeSO}_{4}$ enhances quality parameters. Overall, foliar spray approach is more suitable regarding the availability of nutrients for optimum crop growth and improved grain quality.

\section{Acknowledgement}

Authors are grateful to Department of Agronomy, University of Agriculture, Faisalabad, Pakistan, for providing the land and other resources to conduct the current experiment.
Disclaimer: None.

Conflict of Interest: None.

Source of Funding: None.

\section{References}

Abdullah Z, Khan MA and Flowers TJ, 2001. Causes of sterility in seed set of rice under salinity stress. J. Agron. Crop Sci. 187: 25-32.

Ahmed K, Qadir G, Jami AR, Nawaz, MQ, Rehim A, Jabran K and Hussain M, 2015. Gypsum and farm manure application with chiseling improve soil properties and performance of fodder beet under saline-sodic conditions. Int. J. Agric. Biol. 17(6): 1225-1230.

Aikins SHM and Afuakwa JJ, 2012. Effect of four different tillage practices on soil physical properties under cowpea. Agric. Biol. J. North Am. 3(1): 17-24.

Amin M, Muhammad JK, Muhammad TJ, Masood R, Javaid AT, Muhammad H and Zahir S, 2014. Effect of different tillage practices on soil physical properties under wheat in semi-arid environment. Soil Environ. 33(1): 33-37.

Amini S, Ghadiri H, Chen C and Marschner P, 2016. Salt-affected soils, reclamation, carbon dynamics, and biochar: A Review. J. Soils Sedi. 16: 939-953.

Ashraf M, Muhammad SS, Manzoor A and Muhammad Y, 2003. Effects of different tillage systems on bulk density and sugarcane yield. Pak. J. Life Soc. Sci. 1(1): 69-71.

Azhar M, Iqbal M, Khan MA and Ashraf M, 2001. Effects of tillage implements in combination with gypsum applications on the reclamation of salinesodic soils. Int. J. Agric. Biol. 3(3): 301-304.

Balasubramanian V, Ladha JK, Gupta RK, Naresh RK, Mehla RS, Bijay S and Yadvinder S, 2003. Technology options for rice in the rice-wheat system in South Asia. In J.K. Ladha et al. (ed.) Improving the productivity and sustainability of rice-wheat systems: Issues and impact. ASA Spec. Publ. 65. ASA, CSSA, and SSSA, Madison, WI, 2003, 115-147.

Birkas M, Jolankai M, Kisic I and Stipesevic B, 2008. Soil tillage needs a radical change for sustainability. Agric. Conspectus Sci. 73(3): 131136.

Bohn HL, McNeal BL and O'Connor GA, 1985. Soil Chemistry. 2nd ed. John Wiley and Sons, New York. 
Castillo EG, Tuong TP, Ismail AM and Inubushi K, 2007. Response to salinity in rice: comparative effects of osmotic and ionic stresses. Plant Prod. Sci. 10: 159-170.

Chauhan BS, Gill G and Preston C, 2006. Tillage system effects on weed ecology, herbicide activity and persistence: A review. Aust. J. Exp. Agric. 46: 1557-1570.

Cha-umi S, Supaibulwattana K and Kirdmanee C, 2009. Comparative effects of salt stress and extreme $\mathrm{pH}$ stress combined on glycinebetaine accumulation, photosynthetic abilities and growth characters of two rice genotypes. Rice Sci. 16: 274-282.

Coats B, 2003. Global rice production. In: Smith $\mathrm{CW}$, Dilday RH (eds) Rice origin, history, technology and production. Wiley, Hoboken, pp 247-470.

Dikinya O, Hinz C and Aylmore G, 2006. Dispersion and re-deposition of fine particles and their effects on saturated hydraulic conductivity. Soil Res. 44: 47-56.

Eynard A, Lal R and Wiebe K, 2005. Crop production in salt-affected soils. J. Sust. Agric. 27: 5-50.

Farshid A and Hassan ER, 2012. Physiological characterization of rice under salinity stress during vegetative and reproductive stages. Indian J. Sci. Tech. 5: 2578-2586.

Fukai S and Ouk M, 2012. Increased productivity of rainfed lowland rice cropping systems of the Mekong region. Crop Pasture Sci. 63(10): 944973.

Gopal R, Jat RK, Malik RK, Kumar V, Alam MM, Jat ML, Mazid MA, Saharawat YS, McDonald A and Gupta R, 2010. Direct dry seeded rice production technology and weed management in rice-based systems. Technical Bulletin, International Maize and Wheat Improvement Center, New Delhi, India, 28pp.

Guo Y, Huang J, Shi Z and Li H, 2015. Mapping spatial variability of soil salinity in a coastal paddy field based on electromagnetic sensors. PloS One 10: 1-12. e0127996. doi:10.1371/journal.pone.0127996.

Hamza MA and Anderson WK, 2005. Soil compaction in cropping systems: A review of the nature, causes and possible solutions. Soil Tillage Res. 82: 121-145.

Hayashi S, Kamoshita A, Yamagishi J, Kotchasatit A and Jongdee B, 2009. Spatial variability in the growth of direct-seeded rainfed lowland rice (Oryza sativa L.) in northeast Thailand. Field Crops Res. 11(3): 251-261.

Hoang TML, Tran TN, Nguyen TKT, Williams B, Wrum P, Bellairs S and Mundree S, 2016. Improvement of salinity stress tolerance in rice: challenges and opportunities. Agron. 6 (54): 123.

IRRI, 2002. Rice almanac: source book for the most important economic activity on earth. CABI, Wallingford.

IRRI, 2003. Main weeds of rice in Asia. [http://www.knowledgebank.irri.org. Accessed on 5 July 2011.

Jabro JD, Sainju UM, Lenssen AW and Evans RG, 2011. Tillage effects on dryland soil physical properties in northeastern Montana. Commun. Soil Sci. Plant Analysis. 42: 2179-2187.

Jackson T, Sengxua P and Wade LJ, 2017. Croplivestock systems platform for capacity building, testing practices, commercialization and community learning. Canberra, Australia: ACIAR.

James RA, Blake C, Byrt CS and Munns R, 2011. Major genes for $\mathrm{Na}+$ exclusion, $\mathrm{Nax} 1$ and $\mathrm{Nax} 2$ (wheat HKT1;4 and HKT1;5), decrease $\mathrm{Na}^{+}$ accumulation in bread wheat leaves under saline and waterlogged conditions. J. Exp. Bot. 62: 2939-2947.

Ji B, Zhao Y, Mu X, Liu K and Li C, 2013. Effects of tillage on soil physical properties and root growth of maize in loam and clay in central China. Plant Soil Environ. 59 (7): 295-302.

Jini D and Joseph B, 2017. Physiological mechanism of salicylic acid for alleviation of salt stress in rice. Rice Sci. 24(2): 97-108.

Kaur J and Singh A, 2017. Direct seeded rice: prospects, problems/constraints and researchable issues in India. Curr. Agric. Res. 5(1): 13-32.

Kumar V and Ladha JK, 2011. Direct seeding of rice: Recent developments and future research needs. In D. L. Sparks (Ed.), Advances in agronomy (Vol. 111, pp. 297-413). Academic Press. doi:10.1016/B978-0-12-387689-8.00001-1

Lee KS, Nam JK and Shin HT, 1999. Effective land preparation for wet seeding on a reclaimed saline soil in Korea." Int. Rice Res. Notes. 24: 36.

Licht MA and Al-Kaisi M, 2005. Strip-tillage effect on seedbed soil temperature and other soil physical properties. Soil Tillage Res. 80 (1-2): 233-249. 
Maas EV and Hoffman GJ, 1977. Crop salt tolerance - current assessment. ASCE J. Irrig. Drain. Div. 103:115-134.

Montoroi JP, Albergel J, Bubos A, Fall M, Sall S, Bernard A, Brunet D, Dubee G and Zante P, 1993. "Rehabilitation of rice fields in the acid sulphate soils of lower Casamance, Senegal." In Symposium on Acid Sulphate Soils. International Institute for Land Reclamation and Improvement, Wageningen, Netherlands.

Moon YH, Kwon YR, Ahn BK, Kim DH and Han SS, 2011. Impact of compost application on improvement of rice productivity and quality in reclaimed soil. Korean J. Soil Sci. Ferti. 44: 808813. (In Korean).

Moradi F, Ismail AM, Gregorio GB and Egdane JA, 2003. Salinity tolerance of rice during reproductive development and association with tolerance at the seedling stage. Ind. J. Plant Physiol. 8: 105-116.

Mosaddeghi MR, Mahboubi AA and Safadoust A, 2009. Short-term effects of tillage and manure on some soil physical properties and maize root growth in a sandy loam soil in western Iran. Soil Till. Res. 104(1): 173-179.

Munns R and Tester M, 2008. Mechanisms of salinity tolerance. Ann. Rev. Plant Biol. 59: 651681.

Nam JK and Kwon TO, 1999. Influence of tillage methods on the growth and yield of rice for direct seeding on wet paddy surface of reclaimed saline land. J. Life Sci. Nat. Res. 21: 22-40. (In Korean).

Nayel MH, Farid EAE, Mohamed HD and Abdel Rahman AE, 2016. The effect of tillage system on soil physical properties in eddammer locality of northern Sudan. Ann. Agric. Environ. Sci. 02: 27-34.

Nishimura T, Cha-um S, Takagaki M and Ohyama K, 2011. Survival percentage, photosynthetic abilities and growth characters of two indica rice (Oryza sativa L. spp. indica) cultivars in response to isosmotic stress. Span. J. Agric. Res. 9: 262270.

Ohno H, Banayo NPMC, Bueno CS, Kashiwagi J, Nakashima T, Corales MA and Kato Y, 2018. Longer mesocotyl contributes to quick seedling establishment, improved root anchorage, and early vigor of deep-sown rice. Field Crop Res. 228: 84-92.

Pandey S, Mortimer M, Wade L, Tuong TP, Lopez K and Hardy B, 2002. Direct seeding: research issues and opportunities. Proceedings of the International Workshop on Direct Seeding in Asian Rice Systems: Strategic Research Issues and Opportunities, 25-28 January 2000, Bangkok, Thailand. Los Baños (Philippines): International Rice Research Institute. 383 p.

Pathak H, Tewari AN, Sankhyan S, Dubey DS, Mina U, Virender KS, Jain N and Bhatia A, 2011. Direct-seeded rice: Potential, performance and problems - A review. Curr. Adv. Agric. Sci. 3(2): 77-88.

Pearce AD, Dillon CR, Keisling TC and Wilson CE, 1999. Economic and agronomic effects of four tillage practices on rice produced on saline soils. J. Prod. Agric. 12: 305-312.

Pearson GA, 1959. Factors influencing salinity of submerged soils and growth of caloro rice. Soil Sci. 87: 198-206.

Rickman JF, Pyseth M, Bunna S and Sinath P, 1999. Direct seeding of rice in Cambodia. CambodiaIRRI-Australia Project, Phnom Penh, Cambodia. (Unpublished.)

Rizwan M, Khalil A, Muhammad N, Muhammad FN, Muhammad QN, Sarfraz N, Muhammad A, Adnan U and Imtiaz AW, 2019. Effect of nitrogen application methods and tillage implements on wheat production in salt affected soils. Int. J. Biol. Sci. 15 (6): 194-201.

Rizwan M, Khalil A, Muhammad S, Muhammad QN, Ghulam Q, Muhammad U and Muhammad WI, 2018. Managing sesbania decomposition with urea and different tillage techniques in salt affected soil. Int. J. Biol. Sci. 12 (6): 258-268.

Sadiq M, Jamil M, Mehdi SM, Hassan G and Akhtar A, 2002. Effect of different tillage implements on wheat production in rice-wheat cropping system in saline-sodic soil. Pak. J. Agron. 1(2-3): 98100.

Sarkar RK, Sanjukta D and Das S, 2003. Yield of rainfed lowland rice with medium water depth under anaerobic direct seeding and transplanting. Trop. Sci. 43: 192-198.

Sengxua P, Jackson T, Simali P, Vial LK, Douangboupha K, Clarke E and Wade LJ, 2019. Integrated nutrient-weed management under mechanised dry direct seeding (DDS) is essential for sustained smallholder adoption in rainfed lowland rice (Oryza sativa L.). Exp. Agric. 55(4): 509-525.

Singh TP, 2008. Performance of no-till drill for 
establishment of rice and it's comparison with drum seeder and conventional method. Tech. Sci. 11:12-20.

Siringam K, Juntawong N, Cha-um S and Kirdmanee C, 2011. Salt stress induced ion accumulation, ion homeostasis, membrane injury and sugar contents in salt-sensitive rice (Oryza sativa L. spp. indica) roots under isosmotic conditions. Afr. J. Biotech. 10: 1340-1346.

Steel RGD, Torrie JH and Dickey DA, 1997. Principles and Procedures of Statistic: A Biometrical Approach. 3rd edition, pp: 400-428. Mc Graw Hill Book Co. Inc. New York, USA.

Sweeney DW, Kirkham MB and Sisson JB, 2005. Crop and soil response to wheel-track compaction of a clay pan soil. Agron. J. 98(3): 637-643.

Tuong TP and Bouman BAM, 2003. Rice production in water-scarce environments. In: Proc Water Productivity Workshop, 12-14 November 2001, Colombo, Sri Lanka. International Water Management Institute, Colombo, Sri Lanka.

US Salinity Laboratory Staff, 1954. Diagnosis and Improvement of Saline and Alkali Soils. USDA Handbook 60, Washington, DC, USA.

Wilson CE, Keisling JTC, Miller DM, Dillon CR, Pearce AD, Frizzell DL and Counce PA, 2000. Tillage influence on soluble salt movement in silt loam soils cropped to paddy rice. Soil Sci. Soc. Am. J. 64: 1771-1776.

Xangsayasane P, Senthong P, Chea V, Makara O, Chay B, Jaquie M and Shu F, 2019. A diagnostic on-farm survey of the potential of seed drill and transplanter for mechanized rice establishment in Central Laos and Southern Cambodia. Plant Prod. Sci. 22 (1): 12-22.

Xiong X, Azuma A, Huijun Z, Ken A, Chinao T, Kazuhiko O, Feng L, Huibin J, Chunfeng Z, Baoguo Z, Nannan W, Qingying $M$ and Shucun Y, 2012. Improvement of salt-affected soils by deep tillage. Eng. Agric. Environ. Food. 5(1): 2935 .

Zeng L and Shannon MC, 2000. Effects of salinity on grain yield and yield components of rice at different seeding densities. Agron. J. 92: 418423.

Zhao C, Jiang H, Ren C, Yin Y and Li Y, 2007. Studies on key techniques of sowing rice directly on dry land for high yield and high efficiency. J. Jilin. Agric. Sci. 32: 9-11 (In Chinese with English abstract).

Zhu L, 2008. A report on dry direct seeding cultivation technique of early rice. J. Guangxi Agric. 23: 10-11 (In Chinese with English abstract).

\section{Contribution of Authors}

Anwar Z, Basharat Z, Hafeez MB \& Maqsood M: Designed and conducted the experiment and collected the data

Khan S, Zahra N \& Rafique Z: Analyzed the collected data and prepared first draft 